Research Article

Vuk Uskoković*

\title{
Open-Ended, Metacognitive Conception of Classes for the Advancement of Nonconformity and Creative Thought
}

https://doi.org/10.1515/edu-2020-0117

received December 17, 2019; accepted June 5, 2020.

Abstract: Instructional methods incorporating metacognitive or open-ended elements have been gaining popularity, but synergies between the two have rarely been explored. Created with the aspiration to boost students' knowledge of the knowledge creation process, a conceptually new and structurally open-ended instructional model is proposed here. For that purpose, the squares on Heer's version of the Bloom taxonomy pyramid were turned into steps on which the class climbed from its base to the top. Each step stepped on opened the content initially hidden from view, but corresponding to cognitive and knowledge dimensions intersecting at it, thus turning the content coverage into an open-ended adventure. Both the students in undergraduate and graduate programs in bioengineering and the faculty peers were in favor of the open-ended model of instruction and, based on distributed online surveys, they preferred it over traditional lecturing. In agreement with the adventurous character of the instructional method, frequent detours and diversions from the straight path of the subject were demonstrated as vehicles for the creative thought. As the students ascended along the learning taxonomy pyramid, the content became less foundational and more in need of discussion, analysis and weighing of pros and cons. At the same time, the students would get increasingly connected with the ideas of broader epistemological and ontological relevance. The intellectual pinnacle of the class was achieved at the peak of the pyramid, where the metacognitive and the creative intersected. There, the students were acquainted with the penultimate learning objective, which is the necessity for a professional to question the premises of one's profession through one's

*Corresponding author: Vuk Uskoković, Department of Mechanical and Aerospace Engineering, University of California, Irvine, Engineering Gateway 4200, Irvine, CA 92697, USA, E-mail:vuk21@yahoo.com professional output, alongside providing practical results therewith.

Keywords: Bioengineering; Biomedical science; Biopharmaceuticals; Bloom's taxonomy; Creativity; Metacognition; Recombinant protein; Second-order cybernetics; Science-Technology-EngineeringMathematics (STEM).

\section{Introduction}

\section{"One must have chaos in oneself to give birth to a dancing star"} Nietzsche (1891)

"What the use of writing is to say exactly what we had to say", Emil M. Cioran wondered in one of his essays (Cioran, 1973). Expanding this thought brings us to the conclusion that if we know in advance where we are heading to, there may be not much sense in heading there at all, and if we do not allow a disseminated thought to bounce back and modify the very thought aired, the thought process per se is bound to become stale and sterile after a while. Translating this metalogical thought on thoughts to the educational domain allows for the deduction of two central points that underlie this study. The first is the idea that constant revisions and adjustments of the learning content to the occasion and spirit of the moment, ad-lib, on the fly, are necessary to create an authentic and productive learning environment. The second is the idea that analyses of concepts from metacognitive perspectives, whereby ideas on specific ideas are constantly churned out, is the key to advancing the primary ideas in the creative directions. That metalogical learning about learning is the key to learning consciously and that open-ended, objective-free learning is the best way to spur creativity in the classroom and beyond are, therefore, the two main points around which the following discourse revolves. 


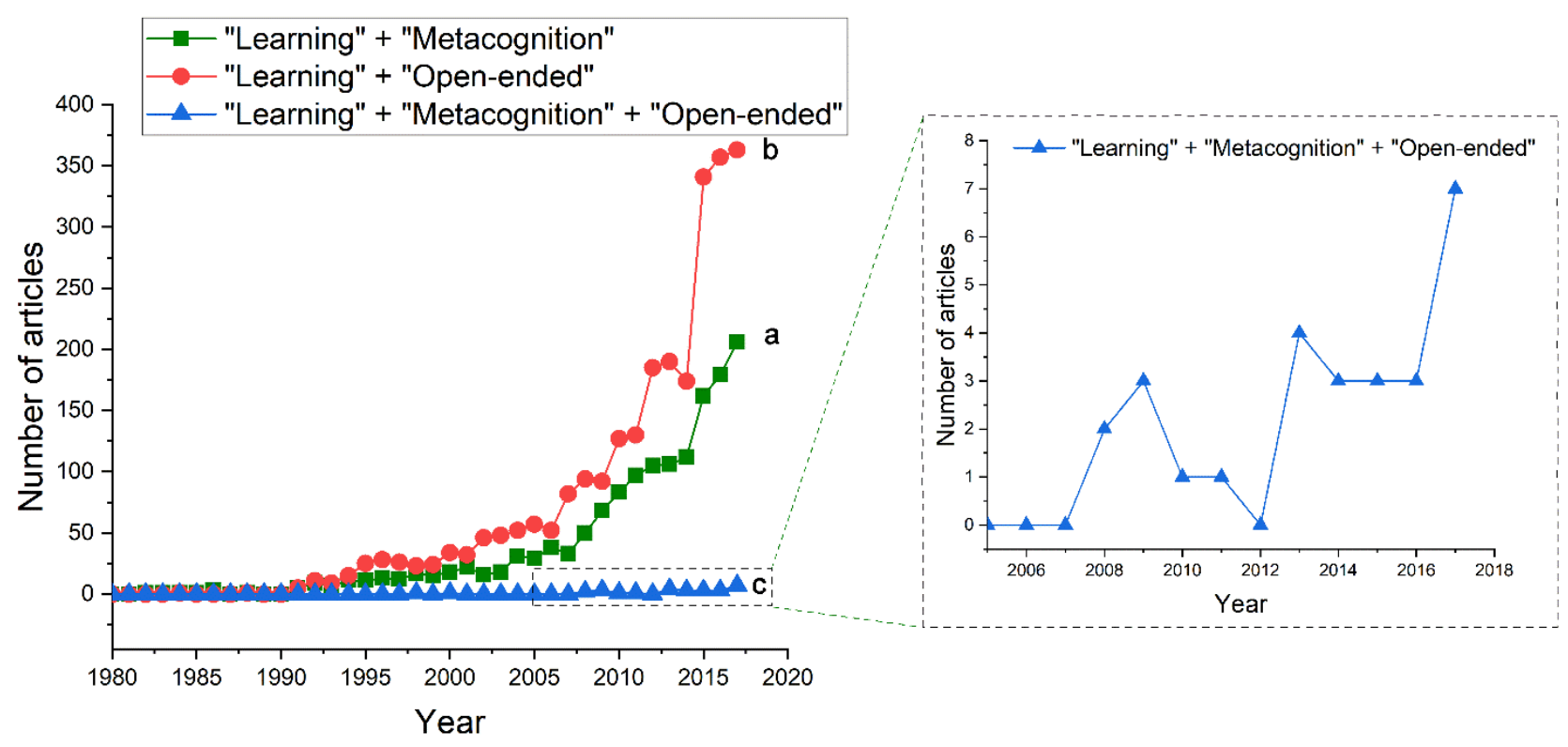

Figure 1: Annually published number of scholarly, peer-reviewed journal articles containing the phrases "metacognition" and "learning” (a), "open-ended" and "learning" (b), or "metacognition" and "open-ended" and "learning" (c) in the topic category for the 1980-2017 period (Database: Web of Science Core Collection, September 2018).

Human brains make rapid strides in terms of the ability to process metacognitive operations in the preadolescent stage of development (Moshman, 1990) and are fully equipped with metareasoning competencies by early teenage years (Santamaria et al., 2013). However, in spite of the comparatively long history of research into the positive effects of metacognition on learning, implementation of metacognitive insights in the classroom setting are still rarely more than merely experimental (Perry et al., 2018). Historically, even though metacognitive effects were discoursed on by philosophers since Plato (Worley, 2018) and the metacognitive process was the subject of intense interest in cybernetics (Ashby, 1952) and constructivism (Fox \& Riconscente, 2008) since the 1950s, metacognition was defined as a term in the 1970s by Flavell (1976) and in the following decade the first reports on its positive effects on learning appeared (Erwin, 1985; Baird, 1986; Biggs, 1988). This was followed by a few hundred studies that reiterated the same positive relationship (Ford et al., 1998; Georghiades, 2004; Yen et al., 2018), only rarely challenged by the studies that partially opposed these findings (Pokay \& Blumenfeld, 1990) and suggested that metacognitive monitoring of one's learning creates a mere illusion of competence (Bjork, 1999; Karpicke et al., 2009; Zawadzka et al., 2018). At the same time, open-ended curricula have clashed with the inclination of the traditional breed of instructors to deliver content in a readymade, prefabbed form.
As a result, instructional methods based on these two principles, namely metacognition and open-endedness, have been extremely rare.

The need for one such hybrid method of instruction, however, comes to prominence after a bibliographic analysis of the number of peer-review articles published annually on the topic of learning coupled to the concepts of metacognition and/or open-endedness. Namely, while the number of articles published annually has been steadily increasing for the separate topics of metacognition and open-endedness in the context of learning, their combined use has been minimal (Figure 1), demonstrating a miniscule increase in the last year, but still averaging at 2.7 articles per year in the last decade (2008-2017) and containing only two entries for the preceding period of time, i.e., up to 2007. This trend suggests a gap in the knowledge on combination of these two concepts in the educational realm, which this study will address.

\section{Experimental Method}

The experimental open-ended metacognitive instructional model was presented to Spring 2016 students in BIOE415, a three-credit-hour senior undergraduate and four-credithour graduate course on biomechanics at University of Illinois in Chicago (UIC) and to faculty peers in the Department of Biomedical and Pharmaceutical Sciences 

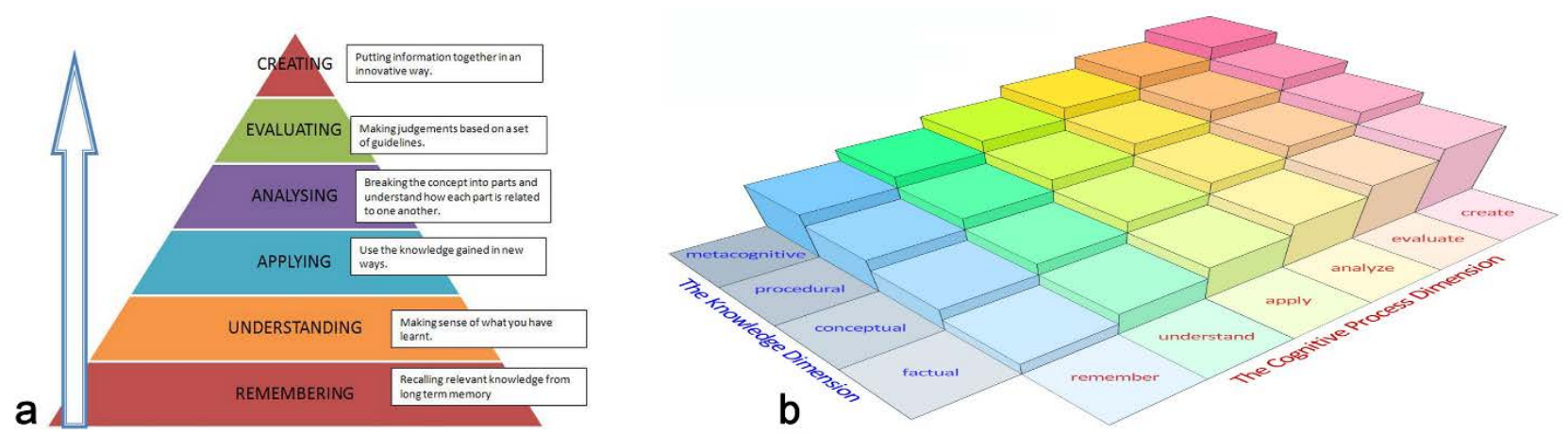

Figure 2: Anderson and Krathwohl's two-dimensional adaptation of the standard Bloom taxonomy pyramid (a) and Heer's threedimensional, interactive version of it (b).

and the Department of Pharmacy Practice at Chapman University in Irvine, California. Information was presented to the student and faculty cohorts in the form similar to a Prezi presentation, which enabled navigation across multiple paths in real time and a more holistic view of the complete content compared to the standard PowerPoint presentation. Students and faculty peers were divided to teams composed of 4-6 members for the active learning exercises implemented in the class. Anonymous surveys assessing the effectiveness of the instruction were distributed to the students and the peers following two different $1.5-2 \mathrm{~h}$ long teaching sessions. The surveys were distributed in the paper format and electronically, using either the Qualtrics platform (Chapman) or an online query spreadsheet (UIC). To eliminate bias, students were not assessed in the experimental class surveyed, while the presentation to faculty peers was performed at a different institution, to a group of faculty previously unknown to the author/instructor. The effectiveness of the methodology of teaching to senior/graduate students and faculty peers was compared against traditional lecturing to comparative populations, namely senior/ graduate students and faculty peers, respectively. The number of respondents to surveys in comparative populations, however, differed, equaling $n=18$ and $n=47$ for the students exposed to the experimental method and traditional lecturing, respectively, and $n=9$ and $n=11$ for the faculty peers exposed to the experimental method and traditional lecturing, respectively.

\section{Findings and Discussion}

\subsection{Associating content with the learning taxonomy pyramid}

The experimental method of instruction made use of the series of adaptations of the taxonomy of educational objectives originally proposed by Bloom (1956). Figure 2a shows the version of Bloom's taxonomy pyramid most commonly in use today. It was derived by adding the "creativity" domain atop the "evaluation" domain in the original, Bloom's version of the taxonomy by Anderson and Krathwohl (2001). The version of the Bloom taxonomy pyramid used in this study was adapted by Heer in 2012 (Figure $2 \mathrm{~b}$ ) and is formed by combining knowledge and cognitive domains into a three-dimensional pyramidal structure (Heer, 2012). Most significantly, at the top of this pyramid, the "creativity" domain from the cognitive process dimension is paired with the "metacognitive" domain from the knowledge dimension.

Preparation for the class involved the association of specific content with each square on this pyramid. The content varied from fully defined on one end of the spectrum, in which case a specific information was linked to each square, to vague and volatile on the opposite end of the spectrum, in which case questions or topics for discussion were tied to the squares. While in the former case the instructor didactically delivered the relevant information, in the latter case the students and the instructor typically co-created the content in situ. Lest the interest of the class dissipate, the character of the content associated with each square varied across the face of the pyramid. As the pyramid was being ascended in the course of the class, so did the questions covered become less elementary and more conceptual in character. In general, as the class ascends from the bottom 


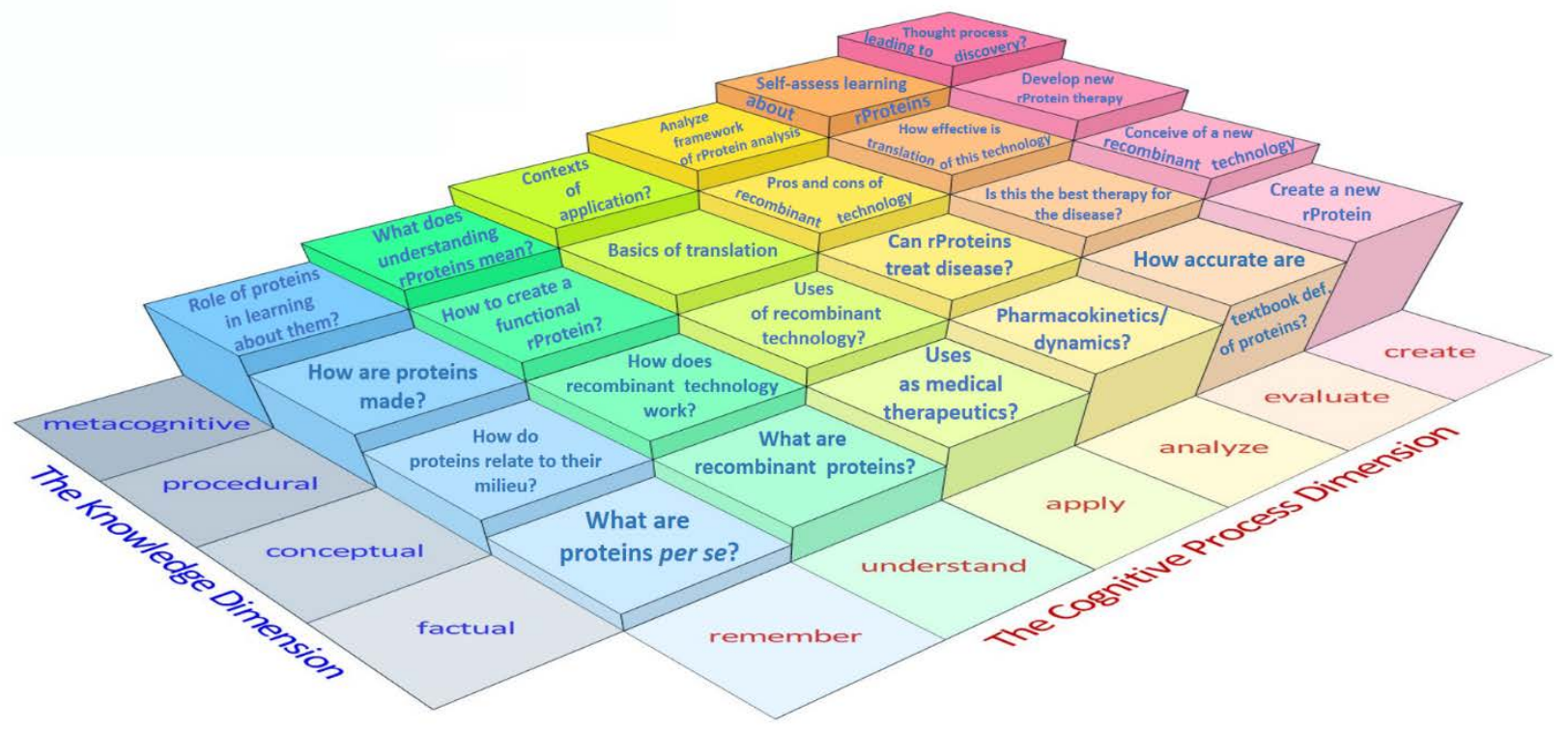

Figure 3: Three-dimensional learning taxonomy pyramid adapted for the purpose of the open-ended instructional model implemented in the class on recombinant proteins and technologies for senior undergraduates in the bioengineering program and PharmD, MS, MSPS, MD and PhD students.

to the top, so does it gradually advance along the scale comprising four cognitive levels, where 1 is Foundational, 2 is Intermediate, 3 is Advanced, and 4 is Mastery. The closer the class is to the bottom of the pyramid, the more foundational the content coverage is, while the closer it is to the top, the more in need of the discussion, analysis and weighing pros and cons of specific ideas the content is. Discussion in this version of the method proceeded partly in the oral form, but was also greatly facilitated using an online service such as Poll Everywhere, where students anonymously posted their ideas on the classroom screen for everyone to see them. Regardless of the actual online service or software used, the opportunities of online networking platforms are advised to be harnessed, as they facilitate textual communication that is more similar in form to the curricular content than oral rhetoric and is also more permanently impressed in the medium, which allows for its steadier analysis.

\subsection{Navigation through an exemplary expe- rimental class}

Heer's taxonomy pyramid adapted for the purpose of teaching the experimental class on recombinant proteins and technologies to senior and graduate student populations is shown in Figure 3. Highlighted in Figure 4 are only the squares opened by the students during the collective ascension from the base to the apex of the pyramid. All squares had specific questions, exercises or other forms of content associated with them (Figure 3), but only those that were opened during the ascension are shown in Figure 4, along with the path taken to the top. Students in the experimental cohort opted for starting from the most basic and the lowest square standing at the intersection of "factual" and "remember" (Figure 4a). There they got acquainted with the chemistry of amino acids, with the nature of peptide bonds and with the four levels of protein structure (Figure 5a), but also with Levinthal's paradox, the intricate concept of quantummechanical protein "breathing" and the effect of polarity of the environment on protein folding. Moving on to the next square, the students chose to advance along the safest, factual edge of the pyramid and step onto the point of intersection between "factual" and "understanding" (Figure 4b). There their goal was to understand the nature of recombinant proteins and how they differed from their natural or chemically synthetic analogues (Figure 5b). They were familiarized with the process of their formation, a.k.a. recombinant technology, on the first following square, where "understand" intersected with "procedural" (Figure 4c). There the students learned about the basics of and differences between molecular cloning and polymerase chain reaction as the two central pathways leading to recombinant proteins. Posttranslational modifications were also covered on this square, along with the choice of host organisms to induce genetic modifications in. After this short detour to 


\section{a.}

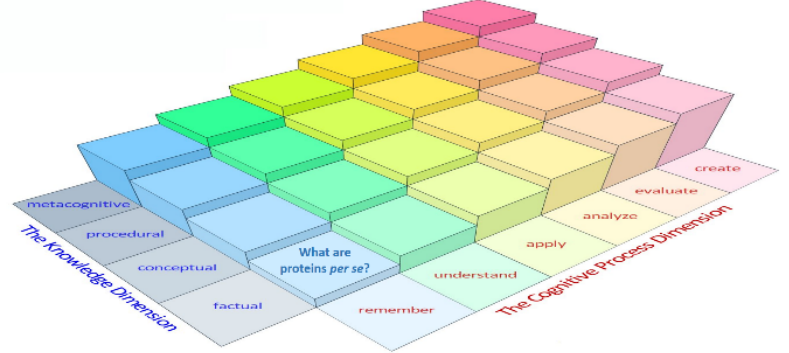

\section{c. How to create a functional rProtein?}

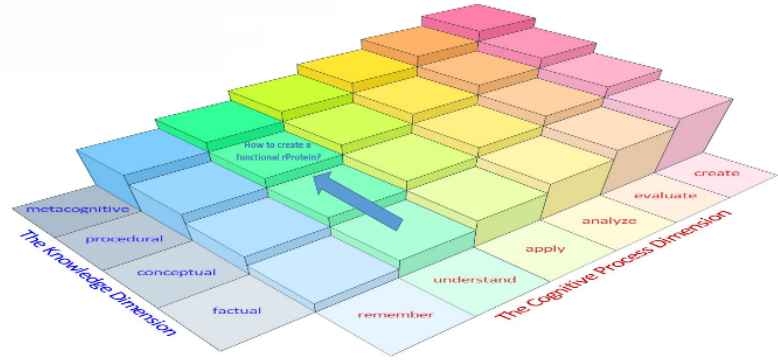

e.

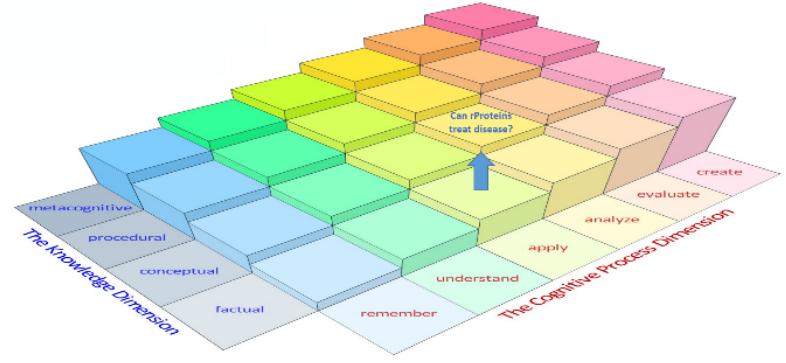

g. Develop new rProtein therapy

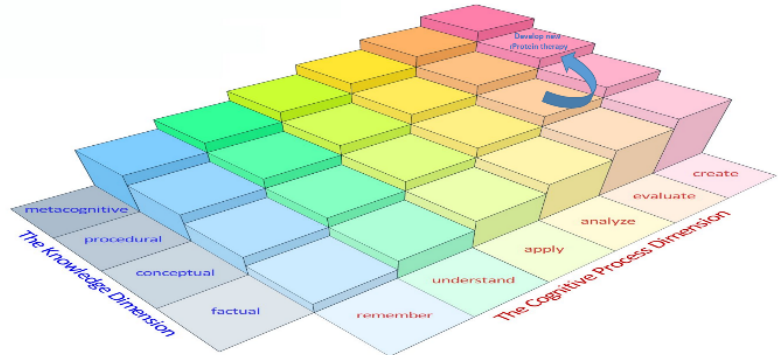

b. What are recombinant proteins?

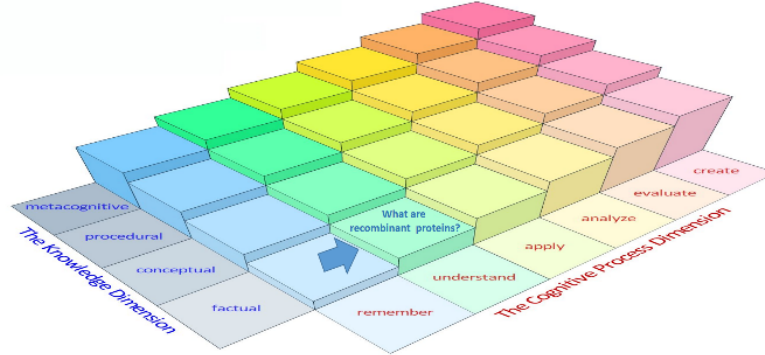

d. Uses as medical therapeutics?

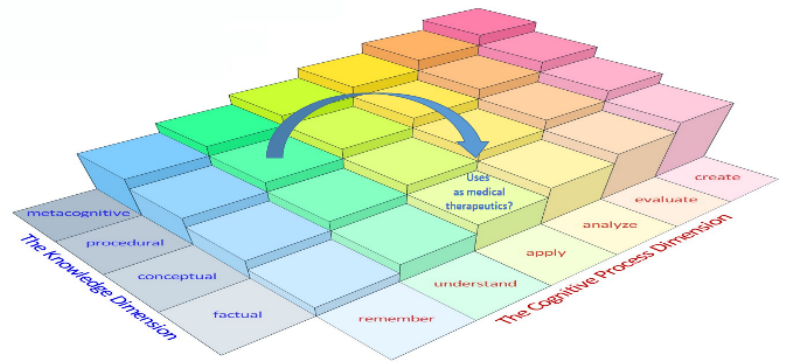

f. Is this the best therapy for the disease?
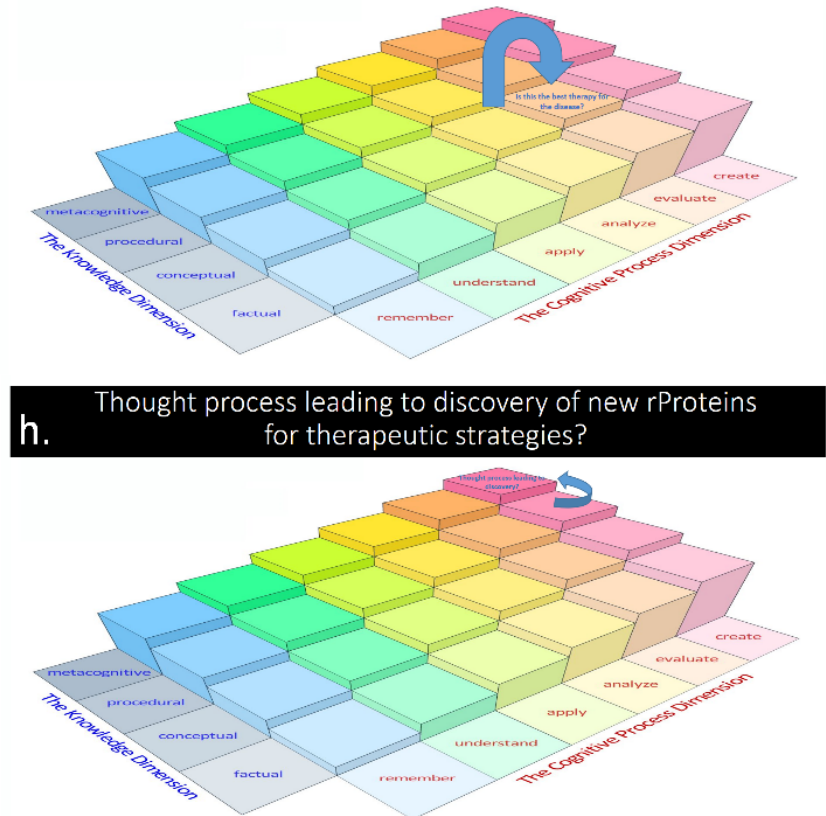

Figure 4: One of the possible ways of traversing the path $(a-h)$ from the bottom to the top of the learning taxonomy pyramid adapted for the purpose of the open-ended instructional model implemented in the class on recombinant proteins and technologies for senior undergraduates in the bioengineering program and PharmD, MS, MSPS, MD and PhD students. This path was chosen by the students in the BIOE415 biomechanics class.

the procedural space, the students voted to go back to the factual edge, where they felt safest and least challenged. There, at the intersection between the factual and the applicative (Figure 4d), they were first acquainted with the basic applications for the recombinant proteins and with their marketing and licensing trends and statistics. Then, because the class at that point already reached decent heights on the pyramid, having distanced itself from the foundational content and approached more complex taxonomies, a game was introduced, where the 

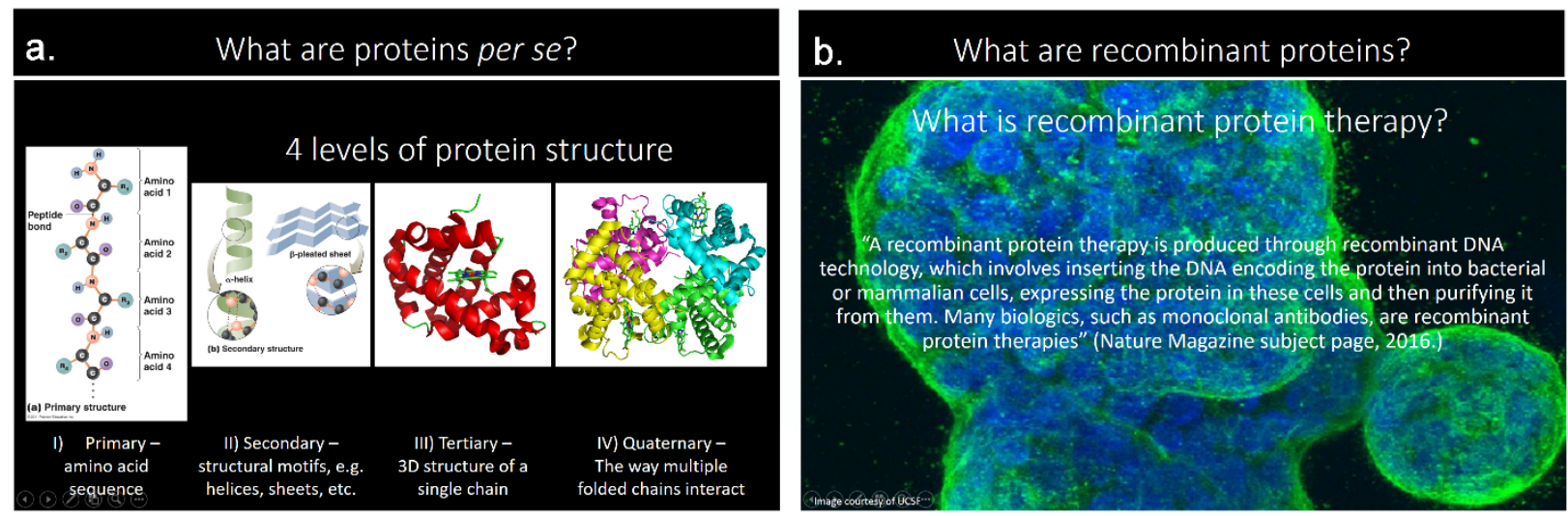

C. Uses as medical therapeutics?
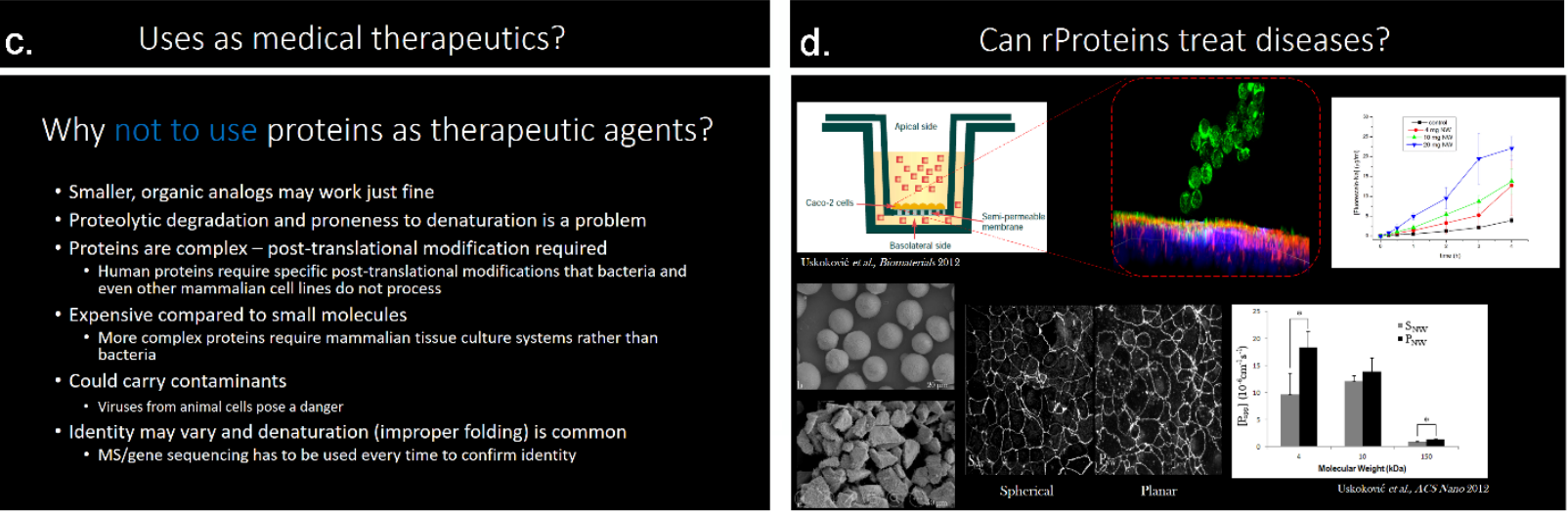

e. Can rProteins treat diseases?
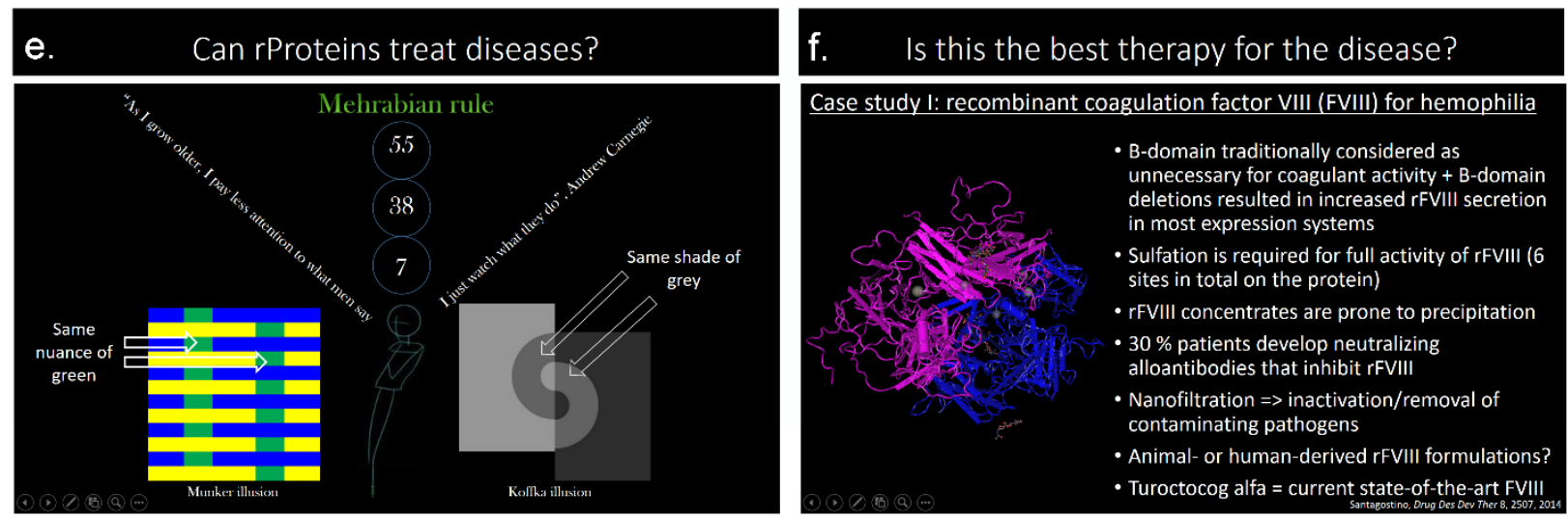

g. Is this the best therapy for the disease?
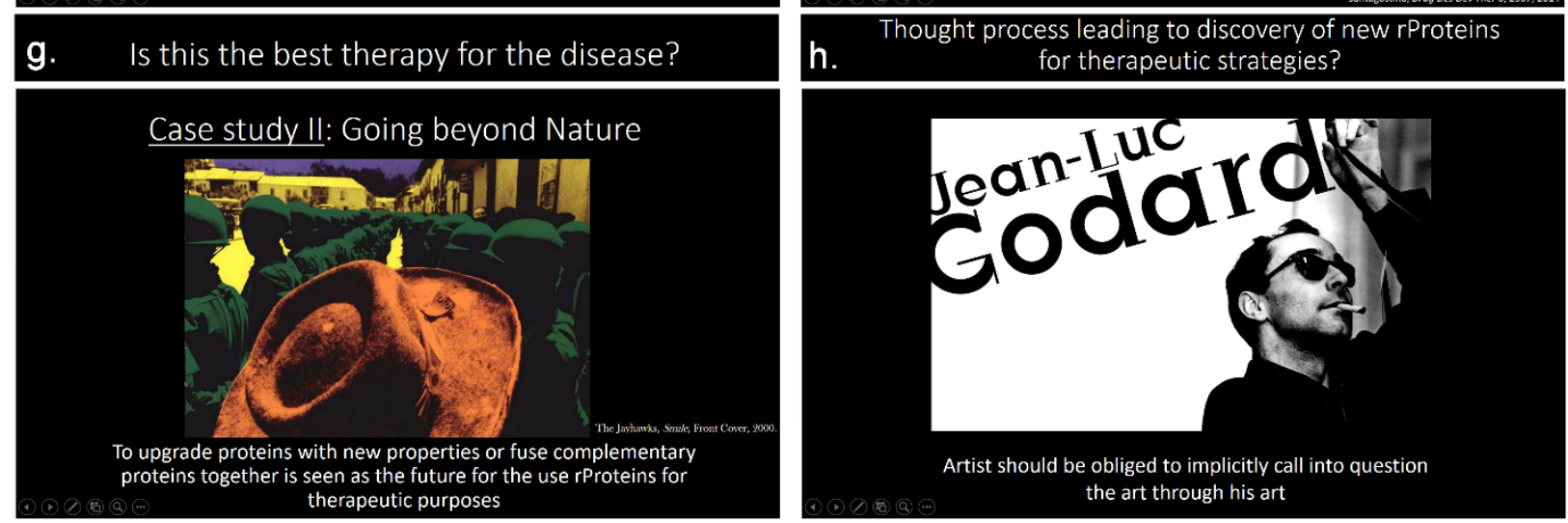

Figure 5: Exemplary slides corresponding to the squares selected by the students as they climbed from the bottom to the top of the learning taxonomy pyramid adapted for the purpose of the open-ended instructional model implemented in the experimental class on recombinant proteins and technologies. 
students were divided to groups, two or more, and given a few minutes to think and discuss the reasons why or why not using proteins as therapeutics - whoever gave more valid reasons would win (Figure 5c). It was announced to the class that if the group in disfavor of using proteins as therapeutics won, the lecture would stop right there. But it did not.

One of the important goals of this lecture, mentioned as one of the learning objectives, was to inspire students to think critically. Critical thinking is rooted in the awareness that nothing is black or white, that everything has its pros and cons, and that even the most revered things have their corrupt sides, while even the darkest nights hold something bright and optimistic. The ultimate purpose of academic education should be exactly that: to fight the bigotry of biased thinking and disseminate the idea that there are pros and cons to everything. One implicit purpose of this exercise was to teach the students of this presence of pros and cons in everything, regardless of how positive or negative it looked. Another implicit point of this exercise was to teach the students that there is always an implicit point to look for in whatever is being offered to them as a message, in or out of classroom. For, whatever the communication in question, the most significant information transmitted by it is not tied to its explicit and capturable content, but emanates from its implicit and ineffable elements (Wittgenstein, 1918; Winograd \& Flores, 1987; von Foerster \& Poerksen, 2002). This is the point to which the class would return at the very final square of the ascension along the learning taxonomy pyramid.

Back tothesubject offactualapplication of recombinant proteins, after the exercise was over and the winning team declared, the instructor complemented the students' insights and deepened the pro/con argumentation, taking it to new directions. The exercise had an empowering effect on the students and they suddenly felt that stepping on to more cognitively complex squares, away from the purely factual, need not be feared. So they moved to the intersection of the conceptual and the analytical (Figure $4 \mathrm{e})$, where they were given the task to contemplate on the question whether recombinant proteins could treat animal or plant diseases effectively. Then came the story about the history of insulin, from its discovery and the rescue of diabetic dogs in 1921 to the production of the first recombinant insulin in 1978 by Genentech to the present era where research worldwide, including the instructor's (Uskoković et al., 2012a, 2012b) (Figure 5d), has been done with the goal to find innovative ways to deliver insulin orally, across the intestinal epithelium. Here the students got to hear about some of the most recent trends in research and development pertaining to recombinant proteins, including the technologies in the translational stage. Here we also touched the general problem of delivery of protein molecules and brought forth the point that systemic diseases are only a small portion of recombinant protein therapies as well as that drug discovery and drug delivery are like two wings of a bird, which must be flapped simultaneously, producing advances on both fronts, in order to enable a straightforward flight. As an illustration of the importance of the contextual effects, it was mentioned that even when we have a perfect drug in our hands, if we do not have the right means to deliver it, our therapeutic missions have failed. This idea was connected with two optical illusions, Munker's and Koffka's (Figure 5e), as a fancy illustration that contexts largely define how we perceive reality. Here, the students were also reminded that, correspondingly, how we present knowledge determines the light in which others would sense and grasp these findings. This metacognitive insight was accompanied by raising the awareness that monotonous lectures could be a greater hindrance to the learning process than it might seem at the first sight. Equipping ourselves with lyrical senses and performance art skills was thus noted as vital not only for facilitating the process of scientific discovery by feeding us with imagination and inventiveness, but also for the effective transmission of knowledge. Poetic sensibility and the craze of a starlit pan cartwheeling on rooftops were from here on consecrated out loudly as the sole ways to overturn Emerson's dismal view on education as an art of lost causes: "It is ominous that this word Education has so cold, so hopeless a sound. A treatise on education, a convention on education, affects us with slight paralysis and a certain yawning of the jaws" (Simmons, 2002). As a crude illustration, here was the time to jump onto tables and proclaim ideas wildly to cause their greater impression in the students than when they were presented boringly and disinterestedly, with no exciting intonation or gesture. Here was also the time to reflect on metalogical writings and all other presentations of thoughts on education in ways that challenge the premises of it as a prosaic, technical discipline. There, instead of engaging in the dullness of technical writing or scholastic speech, the stardust of inspirational insights that falls all around us would be grasped in our hands and hearts and scattered back to the Cosmos and to the starry souls adorning it and the scene before us with timeless beauties, the beauties that, were they wholly absorbed, would produce the Stendhal syndrome of gargantuan proportions, unseen by any man before or after.

These detours and moments when the whole class moves in a sideway direction, seemingly away from the central topic are, in fact, essential for enkindling the fire 
of creativity inside the students' minds. After all, if the uncovering of the content in the class was conceived of as an adventure, then this adventurous spirit should be embedded in every other aspect of the conception of the class. Implicitly, these departures from the topical thread serve to instruct the students that only if they strive for adventure and reinvention of their beings that adventures bring forth, if they constantly set off to new, experimental directions can they become pioneers in their respective fields. For, not only is this "adventure into the unknown" (Feynman, 1998) a precondition for the discovery of new physical or theoretical relationships in natural sciences, but it is also the basis for curiosity, which gets suffocated inside semantic systems that enforce linearity and punish any departures from the plan and turnings back to glimpse the effects not belonging to our supposed line of interest. Thus, the art of questioning, wondering and getting lost in the fields of unknown has to be appreciated as one of the essential drives of creativity. Besides, with Socrates' "knowing of not knowing" being possibly the world's oldest metacognitive maxim and with "one of the hallmarks of experts being that they know when they don't know something” (Pintrich, 2002), making a misstep and getting lost is practically a must in the authentic metacognitive classroom. "Not till we are lost, in other words, not till we have lost the world, do we begin to find ourselves, and realize where we are and the infinite extent of our relations”, Thoreau (1854) noticed, in relation to which a string of invigorating stories were told that drew inspiration from the instructor's personal research and life experience. The soliloquy tied to the instructor as a young man navigating through the backstreets of a seaside town on a carnival night and ending on a dark and desolate top of a mountain, but only to make it a most magical night on the streets below after all, and then to a research project that owed its success to stopping to keep a tight focus on its strict medical goal and starting to roam aimlessly along the sides of the road, where the most important discoveries were made, directing the research back to the central avenue in a far more promising of lights. The storytelling was met with smiles from the students, who understood that without the curiosity and the courage to get lost, many of the major scientific discoveries may have never seen the daylight. Therefore, when students are being accused of "thinking in tangents", as if it is a sin in science, our response should better be that this can be a great quality since science, intrinsically experimental, benefits from authentic, experimentative mindsets, always ready for an adventure, for a voyage into the unknown, for taking on the side roads and getting lost inside the forests of perplexing symbols, for jumping off the cliffs in hope that more blissful continents of thought would be found where their feet land.

Moreover, diverting every once in a while from the main content of a presentation to tell a story that distantly touches the subject that is being discoursed on also keeps the listeners awake and makes them more receptive than linearly proceeding treatises that never stray from the topic. Fosterage of off-topic chatter for more than one-third of the classroom time has been consequently shown to benefit the acquisition of knowledge in an upper-division geometry class (Ernest \& Reinholz, 2018). This seemingly paradoxical principle is a natural consequence of the fact that an essential element of all the intellectual adventures in which we participate is a constant escape from myriads of blind spots that multiply in our views as soon as we settle in them. Scientific creativity feeds on the talent to recognize signs in numerous other fields of interest and bring them along the lines of logic, metaphor or simple emotion to one's own field as fertilizers of ideas, which is why igniters of the awareness of the contextual effects and of "the art of looking sideway" (Fletcher, 2001), inevitably rooted in these meaningful curricular distractions, are needed to boost the creative output of students. Finally, success in creative endeavors is dependent on the skill in operating within multiple contextual spaces rather than being narrow-mindedly focused on a single subject that one holds expertise in. This is especially so in today's interdisciplinary world where not only each scientific discipline crisscrosses multiple other disciplines, but also science in general affects and is being affected by a number of social spheres of influence, from the economic to the political. Or, as Alan J. Perlis (1982) noted in the context of a different, computer science in his epigrams in programming, "When someone says 'I want a programming language in which I need only say what I wish done', give him a lollipop".

Be that as it may, still somewhat shy and insecure, the students continued to proceed to the top along the conceptual file, specifically where it crisscrosses the evaluative row (Figure 4f). There they were given two case studies for analysis, one being about the development of a recombinant protein that replaces a dysfunctional protein and another one being about the efforts to create a protein that goes beyond anything present in the body in terms of functionality or structure. While the former case was exemplified by recombinant coagulation factor VIII for treating hemophilia type A (Figure 5f), the latter case was exemplified by recombinant engineered antibodies for cancer therapies. This was the square on which the students got exposed to the most sophisticated and up-to-date knowledge on the structure and the 
function of recombinant proteins as therapeutics. They learned about immunostimulants, vaccines, antibodies, immunotoxins and fusion proteins as macromolecules typically engineered from the extracellular domain of a receptor and the $\mathrm{F}_{\mathrm{c}}$ portion of a human immunoglobulin, most commonly IgG. These proteins can block specific receptors, inhibit tumor-associated angiogenesis, interfere with the epidermal growth factor receptor (EGFR) signaling and stimulate the recruitment of immune and progenitor cells. The students' imagination got expanded here by becoming aware of various trendy effects in the design of new proteins, such as the use of D-amino acids to build proteins resistant to degradation by proteolytic enzymes or lanthionines as thioether-linked amino acids with enhanced stability and receptor specificity. However, on this square the students also received insights into more systemic epistemological and ontological ideas, and the role of the instructor at this stage was to help them find a path from the minutes of the particular subject to these broader insights. For example, to go beyond Nature, which is the most exciting present and future for the use of recombinant proteins for therapeutic purposes, could lead one to conclude that, in fact, anything creative that we do always differs us from the rest of humanity, while at the same time connects us with it through some shared traits (Figure $5 \mathrm{~g}$ ). When the instructor stands in front of the students and talks, for instance, she uses language, the same as everyone else's, but she tells something new, something that no one expected to hear before, and that fusion of conventional and unexpected is the key to her ability to change the world for better. Here, at this point of the lecture, it was time to challenge, if not drop out loudly, the term "instructor", which, taken literally, has a somewhat derogatory connotation by implying the arrogance of an authority that goes out to tell others what to do and how to be. Rather, in line with this aspiration to broaden the relevance of any given scientific topic and reach out in more inspirational directions than those achieved in the traditional classroom, the "instructor" becomes a "teacher", that is, someone who offers a broader type of education, moral and aesthetic alongside practically focused.

The choice of the squares in this ascension is arbitrary and in this particular class it involved a collective vote preceded by the short discussion within groups seated at individual active learning tables. Apparently, there are no mandatory squares to be stepped on except the highest one where the metacognitive and the creative intersect, being the point at which the most sublime, penultimate goal of education per se lies. Therefore, at this point, the students knew that the move toward the top must be made and boldly stepped on the square on the creativity row, immediately adjacent to the peak of the pyramid (Figure $4 \mathrm{~g})$. On this square where the creative and the procedural intersect, they were given the task to conceive of a novel recombinant therapy. Divided to teams, they let the ideas flourish on each table and presented them in a raw form during the class, when they received an immediate feedback from the instructor, but then went on refine and develop them into a finer form as a part of their homework assignment, the results of which they would present orally in the first following class. For this homework, the students were encouraged to use more inspirational spaces than classrooms, given that the classroom, a listless locus by default, can never be as ideal of a space to harbor illuminative comprehensions as more natural and individualized spaces.

After all of this, as the end of the class was pending, the students were obliged to step onto the peak of the pyramid, even in only for a few minutes (Figure 4h). In this particular class, there they got to hear about two figures: Jean Luc-Godard (Figure 5h) and Shinya Yamanaka. The former is an artist who has served as an inspiration and reference point that $\mathrm{I}$, the instructor, repeatedly returned to during the academic career so as to never lose track of the dual purpose I have aspired to achieve with my scientific output: (a) to create new knowledge, and (b) to question how this creation of new knowledge could proceed in more effective ways and ways that instill a greater harmony in the heart of man (Uskoković, 2018b). While the former aim is logical, the latter is metalogical, requiring metacognitive skills to be understood and accomplished. Godard is an artist who has done exactly that, though in the realm of cinema: by authoring captivating films that simultaneously questioned the art of cinema, he struck a balance between cognitive and metacognitive. As for arts, of course, the creation and transmission of fundamental or practical knowledge is substituted with the connection with the viewer on the emotional plane. Trivially speaking, most soap operas and cinema blockbusters provide this connection, but they rarely ever provide the viewer with anything profoundly valuable in terms of historically relevant insights into the essence of the given medium and the form of art. So how do we avoid our science becoming the analogy of a slushy telenovela or a vacuous Hollywood film? By understanding these deep, metacognitive foundations of scientific thought. Sartre's imperative was that an artist must question his art through his art (Roud, 1968), and so should the penultimate learning objective be the ability to question one's thought process and the prosperity of the path on which science in the given field is. That was the 
aim posed before the class before it even embarked on this adventure that it has grown into.

As another illustration of the idea that metacognitive insights play a key role in the process of scientific discovery, the story of Yamanaka's discovery of the method for transforming primary cells back to stem cells was presented to the students. Namely, he perceived the global efforts in his field from a metacognitive perspective when he realized that everybody's goal was to direct the differentiation of stem cells into various phenotypic lineages. Possibly recalling Chesterton's norm that dead things can move only with the stream, whereas only things that are alive can move against it (Chesterton, 1925), he decided to travel the opposite route, against the mainstream and opposite to the trend. Thus he began to study how to convert fully differentiated cells back into their pluripotent state. After years of research, he succeeded in using transcription factors to convert somatic cells to pluripotent stem cells (Nakagawa \& Yamanaka, 2010), which can differentiate into any type of cell in the body, thus changing the face of regenerative medicine for good. Once again, at this point, the instructor - always eager to bring up-to-date research topics into the classroom discussion, lest the students neglect that the purpose of education is not to chew the trite old canons, but to keep everyone at the edge of the unknown, where the creative ideas fostering the discovery process can flourish - reverted back to his area of expertise and told the story of how his aforementioned research evolved from attempting to use bone mineral nanoparticles as mere carriers for antibiotics to treat bone infection with to falling in love with the carrier itself and, after studying it for years, beginning to see the means as ends and the carrier as the therapeutic agent to, finally, turning the initial approach up on its head and proposing bone mineral not as a target of the treatments, but as their source (Wu et al., 2018). This was all to illustrate that tirelessly observing one's profession from metacognitive angles can be a powerful booster of creative thought and the source of innovative directions hidden from view to anyone unready to step onto these elevated and holistic cognitive panoramas.

\subsection{The need for in situ adjustments of the content}

If there are no two identical grains of sand on Earth, there could not be two sentient creatures either that yearn for the same answers to questions that arise inside their minds. Knowing this, a mechanical habit of yielding an identical response to each student that comes to the instructor to satisfy his/her inquiries cedes its place to an adventurous habit of always looking for a novel response, unique in space and time from now until the end of the Universe. Teaching, as such, becomes an incessant improvisation played atop the premise that everybody is unique and requires unique instructions to fit his/her cognitive needs and be driven in the creative direction. The instructional model presented here complies with this demand by allowing for the content to be adjusted in situ to the interests of the class. Thus, in the extreme cases, a class that is predominantly fact-focused would gravitate toward the far right, factual side of the pyramid; a class that is oriented mostly towards gaining practical skills would tend to move along the procedural series of steps in the center of the pyramid; a class that is drawn to the understanding of relationships and patterns pervading the subject would be inclined to ascend via the conceptual series of steps; finally, the more philosophically zealous class would be attracted to the far left, metacognitive edge of the pyramid.

Moreover, it can be argued that for the instructional method to be fully authentic in its open-endedness, the content must be completely moldable and adjustable to needs and interests of the class. To that end, the method proposed here could take on a didactic approach, but can also be combined with the previously elaborated co-creative (Uskoković, 2018a) and/or co-productive (Hubbard et al., 2017) methods of instruction by turning questions on each square (Figure 3) into starting points for the collective engagement of the class in the creation of the content answering them or, perhaps, as per Bateson's take on Cummings' maxim, providing answers that "ask more beautiful questions" (Bateson, 1979). In fact, it is often forgotten that the posing of a prefabbed path before students intrinsically assumes an arrogant stance that implies that the instructor knows best what is best for the students, while neglecting the morally and epistemologically toxic influence of taking on such a stance. In contrast, opposing the intrinsic arrogance, let alone ignorance, of such curricular paths set in stone, the experimental method proposed here is immune to handing over questions, problems or exams with fixed, predetermined answers, in part because this would insult the students' intellects and in part because it would pose roadblocks before the pioneers' strides along the path of discovery. Finally, this incessant self-invention and innovation in expression serves to highlight, humbly, the imperfectness of the instructor's knowledge, thus intrinsically nurturing the antiauthoritarian, nonconformist standpoints, which are the bases for the exhibitions of creative thought. After all, without noticing 
flaws in the fabric of reality and/or human knowledge in a nonconformist manner, these flaws can never be fixed and knowledge would never evolve past its current, indisputably deficient form.

\subsection{Peculiarity of the pyramid steps}

One of the frequent complaints heard from students is that instructors throw disconnected facts at them and do not make enough effort to compile them into coherent stories. Instructors' instructors thus often turn to the analogy with LEGO blocks: a good lecture, according to them, may start off from a random pile of blocks in the preparatory stage, but when presented to the students, it should be a fully assembled LEGO set. The content-laden version of Heer's taxonomy pyramid elaborated here presents one such set that naturally facilitates the assembly of individual points into well-arranged and orderly wholes. It is a skeleton that prevents the dissipation of the lecture content into a collection of disparate facts and helps organizing them into holistic and hierarchically organized edifices. At the same time, knowing that some of the information embedded in the pyramid squares will not be opened as the class progresses from its bottom to the top increases both the value that students ascribe to knowledge on this subject and their receptiveness to it. It makes them more wide awake in contact with this knowledge in class than in a case where knowledge were to unfold inertly and linearly before them. Also, in order for this selective unfolding of knowledge before students and by students to make sense, a discussion is to accompany the opening of each square, given that after the class the students would gain access to the content associated with the squares omitted during the class. In simple terms, without their gaining an epistemic benefit from the selection process, the selection per se cannot be justified. The instructor's role is to create an atmosphere in the class that makes these benefits positive rather than negative, that is, to make students look forward to opening some squares because they would get exposed to enriching information thereby and not because they would avoid, for example, difficult calculation or intricate derivation on an unopen square.

Epistemic grounds of the model elaborated here present an extension of the educational and ethical philosophy advocated by the first- and second-order cyberneticians of the $20^{\text {th }}$ century. The fosterage of a more practical thought in cybernetics, revolving predominantly around the idea of artificial intelligence and having direct ties to the mass-produced electronic gadget market, has pushed this generation of renaissance thinkers, the last one to take the world as a coherent movement, if not by the storm, down to its dim backstage. At the same time, many of their romanticist ideas, which they allowed to spontaneously emerge from their science and guide it in creative directions, have been left to decline, having no critical mass of followers to expand them. Ironically, cybernetics as a science emerged from the control theory, but this did not prevent these inventive thinkers to find fundamental deficiencies in the concept of control per se and repeatedly asserted their beliefs in the toxic, deleterious effects of the attempts to control anything or anyone. The early cyberneticians hinted at this idea from within different analytical frameworks, including the mathematical (Ashby, 1956) and the rhetorical (McCulloch, 1965), whereas their immediate followers justified it from more explicit angles (Maturana \& Verden-Zöller, 2008; Glanville, 2003). Its implementation necessitates the destruction of the authority present in the hands of the instructor alone and its distribution over the entire classroom, as in accordance with the anticolonial and anarchistic school of thought more recently proponed by Friere (1993) and Hooks (1994) within the educational realm. The will to power, as it were, must be obliterated and open-ended learning presents a step toward reaching that goal. The steps of the pyramid presented in this educational model are, in that sense, but steps toward this sublime goal.

\subsection{Results of the surveys}

As indicated by the results of the surveys, both the students and the faculty peers were in favor of the openended model of instruction. Half of the student attendees judged the quality of the class with the highest mark, 38.9 $\%$ of the class thought that the quality was above average and only $11.1 \%$ of students thought that the class was average in quality (Table 1.1). The majority of students thought that the method is effective for learning (Table 1.2); that it provides them with the optimal amount of information (Table 1.3); and that they would be very likely to enroll in a course offering this method of instruction (Table 1.4). The response of faculty peers was even more overwhelmingly positive (Table 2). The students' and faculty peers' written comments further reiterated the relevance and the effectiveness of the method (Table 3). No negative comments or comments expressing indifference were noted. Both the students and the faculty peers also preferred the experimental open-ended model of instruction over traditional lecturing by the same lecturer (Figure 6). However, the difference between the degree 
Table 1: Statements from the survey distributed among students $(n=18)$ on the perception of learning using the metacognitive, open-ended teaching model. Bolded are statements with the highest level of agreement within the group.

\begin{tabular}{|c|c|}
\hline Statement & Level of agreement (\%) \\
\hline 1.a. The method is excellent & 50 \\
\hline 1.b. The method is above average & 38.9 \\
\hline 1.c. The method is average & 11.1 \\
\hline 1.d. The method is below average & 0 \\
\hline 1.e. The method is poor & 0 \\
\hline 2.a. The method is effective for learning & 61.1 \\
\hline 2.b. The method is somewhat effective for learning & 38.9 \\
\hline 2.c. The method is ineffective for learning & 0 \\
\hline 3.a. The method overwhelms with the amount of information & 11.1 \\
\hline 3.b. The method somewhat overwhelms with the amount of information & 33.3 \\
\hline 3.c. The method provides optimal amount of information & 44.5 \\
\hline 3.d. The method provides insufficient amount of information & 11.1 \\
\hline 4.a. I would be extremely likely to enroll in this type of class & 16.7 \\
\hline 4.b. I would be very likely to enroll in this type of class & 44.5 \\
\hline 4.c. I would be likely to enroll in this type of class & 27.8 \\
\hline 4.d. I would be not so likely to enroll in this type of class & 5.5 \\
\hline 4.e. I would be not at all likely to enroll in this type of class & 5.5 \\
\hline
\end{tabular}

Table 2: Statements from the survey distributed among faculty peers $(n=9)$ on the perception of learning using the metacognitive, openended teaching model.

\begin{tabular}{ll}
\hline Statement & Level of agreement \pm SD (\%) \\
\hline a. The method is organized & $97.5 \pm 7.1$ \\
b. Learning objectives are clear & $97.5 \pm 7.1$ \\
c. Crucial concepts and ideas are conveyed properly & $92.5 \pm 10.3$ \\
d. Current methodology/information is incorporated & $95 \pm 9.2$ \\
e. Audience is actively engaged & $97.5 \pm 7.1$ \\
f. Information is well communicated & $97.5 \pm 7.1$ \\
g. Questions are answered appropriately & $95 \pm 9.2$ \\
\hline
\end{tabular}

of positive perception of the experimental open-ended model tested here and the degree of positive perception of the traditional lecturing by the same instructor was significantly greater in the student evaluation group than in the peer faculty group. This can be interpreted as either a greater aversion to traditional, didactic lecturing among the students compared to the faculty or a greater attraction to interactive, experimental models that feed on the input to the content to be learned by the learners themselves. This can be explained to some extent by the fact that the faculty peers went through the traditional education, which involved mostly one-way transmission of information from the instructors to the students, as opposed to today's students, which, as these results suggest, crave more of the interaction and active input through which the learning content is flexibly molded to their learning style and interests. This brings us over to another positive feature of the open-ended instructional model, which is its appeal to the videogame generations. The proportion of recreational videogame players among 

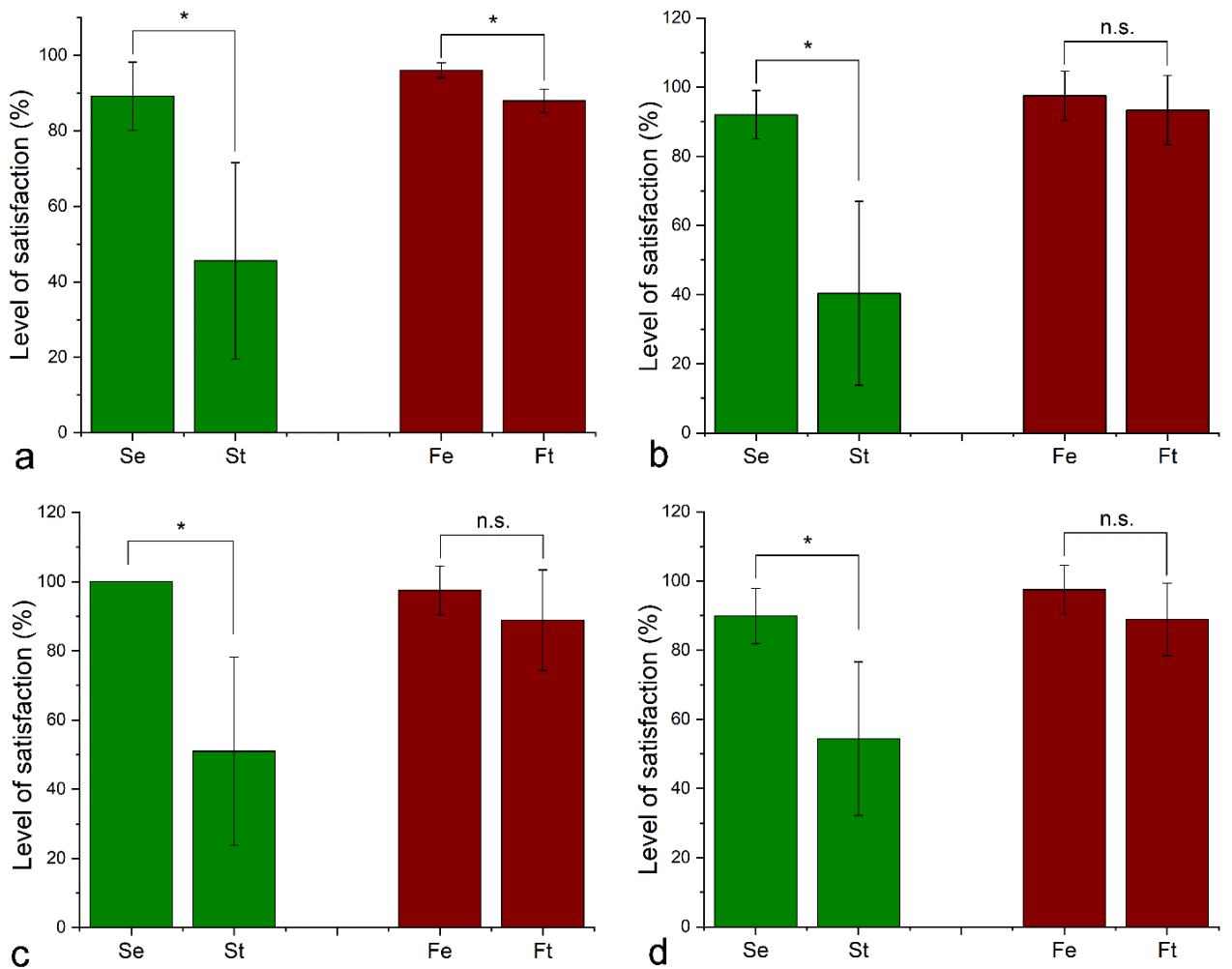

Figure 6: Comparison of different aspects of student and faculty perception of the experimental open-ended instructional method and traditional lecturing delivered by the same instructor: (a) overall quality; (b) level of engagement; (c) effectiveness of communication/ instruction; (d) structuring and flow. Se - student perception of the experimental open-ended instructional method; St - student perception of traditional lecturing. Fe - faculty perception of the experimental open-ended instructional method; Ft - faculty perception of traditional lecturing. Data points represented averages of $n$ numerical values, where $n=18$ for Se, $n=47$ for St, $n=8$ for Fe and $n=11$ for Ft. Error bars represent standard deviation. Statistically significant differences between comparative sample groups $(p<0.05)$ are marked with an asterisk. Statistically insignificant differences between comparative sample groups ( $p>0.05)$ are marked with n.s., meaning "not significant”.

Table 3: Comments made by the student (1.a-b.) and faculty peer (2.a.-g.) attendees of the experimental open-ended class on recombinant proteins and technologies.

\section{Comments}

\section{1.a. Great approach}

\section{1.b. I wish we would have done this type of activities in other classes}

1.c. I loved all the cultural references, especially about Godard

\section{2.a. Almost perfect teaching presentation}

2.b. Complex concepts are presented in an understandable way

\section{2.c. Excellent teaching style}

2.d. Very effective teaching

2.e. Great presentation

\section{2.f. Excellent teaching}

2.g. I personally liked the interactive teaching in the teaching presentation students has steadily increased over time (Prensky, 2001) and this population is expected to find interactive, openended instruction more resonant with their learning style than the classical methods based on unilateral expositions of information. A number of successfully implemented instructional methods incorporating games serves as a testimony to the actuality of interactive, inherently playful education (Gorgen et al., 2020; Liuta et al., 2019; Veldkamp et al., 2020), especially for today's student cohorts heavily influenced by the videogame culture.

\subsection{Open-ended assessment?}

The question naturally arising at this point is if assessment could be conceived of so as to be equally open-ended as the content coverage? Yes, but it would be a bold move, not necessarily embraced by the current trends in academic administration. As a reminder, the current 
trend in academia is not to loosen the strictness of the grading schemes, but rather to diversify them and make them more militaristic in nature. For example, one of the problems observed in the flipped classrooms has been the negligence of students to get familiarized with the preclass content so that they could participate productively in in-class content comprehension and analysis activities. Grades calculated into the final grade in a typical class have thus multiplied over the years; in addition to those earned on regular exams, they now include grades earned on (i) quizzes at the beginning of the class to ensure that the pre-class content was gotten acquainted with and grasped; (ii) quizzes posed at the end of the class to ensure that the students participated properly and not just sat around absentmindedly; (iii) attendance sheets often filled automatically, containing the percentage of the class physically attended, as in the case when students sign in as they enter the classroom through the IP address of the local server accessible only in the given classroom; and so on. The triviality of this trend where new grades and subgrades are being continuously churned out is rarely interpreted at the level of its implicit message, which is that students, if in need of increased conditioning by their means, are regarded as intrinsically irresponsible, disinterested and lazy. Excessive reliance on grading can be condemned for raising sheepish conformists and lawabiders before whom the secrets of creativity will never be fully unlocked. As time goes by, this conditioning through assessment will prove to have powerful, albeit subtle and little noticeable, amoral repercussions. For, through this inherently oppressive form of conditioning, fine but unrepairable damages are done to students' psyches, predisposing them to intuitively conceive of actions that are equally oppressive later in life, thus perpetuating the cycle of pollution of innately pure juvenile minds. This becomes even more tragic when one takes into account the fact that most educators are aware that the truest form of instruction should be like a sea into which the rivers effortlessly flow, with no pressure exerted on them at all, but they buy into the central academic dogma that the oppressive force of authority must be imposed onto students and correspondingly rely on immanent punishments to keep control of the class. Most of the time, this choice of theirs is justified by the obedience to higher authority because of the fear of the loss of their academic positions had they resorted to more anarchic standpoints, but also by the addiction to their own authority, that single drug stronger than opium.

Contrasting the assessment philosophies rooted in unnatural determinacies and an equally unnatural stiffness of the authorities imposing them, one is free to imagine an open-ended assessment model reflective of life, where questions and answers would coevolve in incessantly new directions, the way life does, instead of being predetermined, simplistically reflective of the content and supportive of robotic repetitiveness. The outcome of the hypothetic implementation of one such model would be a broad distribution of grades, from the lowest to the highest, not even nearly reflective of the students' ability to reproduce the content, and this would be so heavily disliked by both the students and the administrators that it might, as in the author'scase, resultin excommunication from academia. However, to discourage the failure through the enforcement of assessment models that are reproductive rather than inventive in nature and that test only the very bottom of Bloom's taxonomy is to, effectively, discourage the evolution of juvenile minds into groundbreaking thinkers and boundary shifters. A longterm positive effect of one such open-ended assessment model would be that it would slowly get the students used to the fact that their grades will not really be reflective of their ability to reproduce the content. Most of the time their grades would not be reflective of their demonstration of inventiveness either, given that this aspect of academic performance is impossible to measure and assess in the classroom setting, that is, away from the research environment. However, to trivialize the grades, those barriers of mistrust between students and teachers, is to win an important battle in the academic circles, and this is exactly what can be achieved through the expansion of the concept of open-endedness to the assessment arena.

\subsection{Learning objectives and class size/ duration}

One aspect of the open-ended method discussed is that only tentative and systemic, but not definitive learning objective(s) could be iterated at the commencement of the class. Setting forth learning objectives, especially in the highly specific form which they are being requested to possess in today's academia, is usually followed by conceiving a path set in stone that would lead to them. However, since that sort of path is absent in the method elaborated here, no standard, highly specific learning objectives can be aired before the end of the class either. Learning objectives, however, can still be wrapped up toward the end of the lecture. Still, the only certain learning objective in this method is metalogical in nature, which is in agreement with the idea that making learning the learning the penultimate learning objective is a must in curricula whose goal is to foster creative thought rather 
than sheer regurgitations of facts and reiterations of paradigms. The accomplishment of this goal, needless to add, is like a mountaintop that can be reached from an infinite number of angles and by following an infinite number of different paths.

The instructional model described here benefitted from the comparatively long duration of classes, ranging between 1.5 and $2 \mathrm{~h}$. There was a significantly lesser loss of attention observed in the students in comparison with traditional lecturing, one reason being that a comparatively long class was made up for by (i) a diverse content coverage that varied from one square to another, and (ii) an interesting storyline evoked by the ascension to the top of the learning taxonomy pyramid. In contrast to the majority of (inter)active learning models, where the successful implementation of the model is inversely proportional to the number of students in the class, this model was successfully implemented in a setting averaging a dozen students, but also worked well in bigger settings $(75<n<100)$. In the latter case, PharmD students were seated at 10-15 tables in an active learning classroom, surrounding the instructor and working in teams of 6-8 students each. Since this is a type of model dependent on the active involvement of the instructor, the back and forth communication between her/him and the students is essential and it is difficult to expect that the use of technology could substitute this human role, which goes hand-in-hand with the inherently artistic character of education in general.

\subsection{Ties between metacognition and open-endedness}

The idea of tying the representation or active creation of the content to different levels of the learning taxonomy is metacognitive per se. In addition, however, each class is concluded first with the analysis of the content resting on the peak of the pyramid, where the metacognitive intersects with the creative, and then with a collective metalogical analysis revolving around the questions of what has been learnt and why. Rather than reflecting on how the material has been learnt and focusing on the mechanism of the learning process, here the emphasis is on gaining insight into the knowledge of knowledge, that is, on the flaws and important features of the material grasped in an array of contexts. Once on top of this metacognitive pyramid, students are also usually invited to discuss the connection between these two main points: the open-endedness and metacognition. Thus, they are usually reminded that according to Gödel's second incompleteness theorem, which shows that a logical system cannot demonstrate its own consistency, every metalogical analysis must remain by its very nature open-ended. Godard, the figure seated at the top of this pyramid in the class exemplified in Section 3.2, was aware of this fundamental flaw in the fabric of the metacognitive thought when he said that "we can make anything except the story of what we're making" (Godard, 1998).

All in all, metacognition alone is an insufficient driver of a truly comprehensive learning process and must be complemented with the development of right sets of beliefs, socially intelligent outlooks and motivational tools (Zimmerman, 1995). On the other hand, if questions about values are central to education (Smith, 1996), then self-referential perspectives and arguments must be provoked and metacognitive tools employed as a part of the curriculum and we become spun within a causally circular feedback loop. Such epistemic tools that foster reflection, however, are best implemented in a collaborative, socially interactive milieu (Moshman, 2003). With interaction being disabled in an authoritarian environment that enforces specific paths to be crossed and does not allow for the molding of the content and the learning paths to the occasion, it can be deduced that the open-ended character of the curriculum must be a natural accompaniment of any metalogical perspectives employed in the classroom. Besides, it is worth recalling that none other but the force of conscience embodied in the form of a recursive, self-referential riddle, was used by Jean-Luc Godard to dismantle the omniscient, but tyrannical Alpha 60 computer in the sci-fi cinematic story about the dystopian city called Alphaville (Godard, 1965). This is to suggest that metacognitive insights are essential for healing everything that has become lifelessly robotic in instructors and the students. They are also the key to having students "learn the difference between sheer skill and skill that is linked to spirit, expressiveness and personality... between the artist who does art well and the artist whose works breathe life and imagination into materials to say something" (Rothko, 2006), the difference that, albeit being traditionally important to establish in arts education, has been virtually foreign to education in hard sciences, where the mechanistic know-how is more or less everything students nowadays expect to receive and instructors are prepared to teach, yielding a state of affairs that signals a pending transition of universities to vocational schools, with consequences too bleak to be foretold. But with a little bit of intellectual subtlety, they could be turned into beautiful question marks dropped in the midst of the current academic streams that shift the pedagogic priorities from training for creative expression 
to training for sheer craftsmanship, stemming naturally from the fosterage of conformity, machinelike reliability and adherence to authority on the account of sidelining the quests for originality, inventiveness and changeability, which plagues the vitality of thought in science departments and feeds, obviously, on the lack of a broad and holistic metacognitive curiosity. And with conscience being defined in psychoanalytic terms as the component of superego that performs a metacognitive function of overseeing the ethical character of one's thoughts and actions before conveying these second-order insights to ego for consideration, it can be concluded that ascents to these peaks of Heer's taxonomy pyramids are, naturally, the routes for the simultaneous fosterage of creativity and humanization of our sciences, so badly needed in today's STEM world where the threads tying natural sciences to art, aesthetics, morality and philosophy get thinner with each passing day, rapidly approaching the point of rapture with unforeseeable consequences.

\subsection{Future research directions}

Future directions of research on an instructional method that is open-ended in nature must be similarly directionless and unbound by prefixed plans. Consequently, the only proper way for this method to evolve is through impromptu exploration with the input of all parties touched by it: the instructor(s), the students, the administrators as well as the peers and the public, including the readership of this piece. The indefiniteness of the direction to move in aside, there are definite points around which the future research on this model intends to revolve, including the following:

a) In the current version of Heer's taxonomy pyramid, the content-containing steps are prefabbed, be they opened or remaining hidden during the class's ascent to the top, and one goal is to conceive of steps whose content would be co-created in situ by the class, in response to its fluctuant interests and the echo of the questions and answers aired in the past. Falls from the edge of the pyramid may thus become possible too if the class strays in unsound directions and, like most falls in the realm of human thought (Uskoković, 2009), they may provide an even greater opportunity for learning than smooth uphill rides do.

b) Enlarging the scope of metacognitive insights lurking from the top of Heer's pyramid and ensuring their coverage of multiple aspects of the learning process uncovered here. Ideally, learning as a concept would be redefined with the provision of such metacognitive perspectives and no longer perceived as an authoritative and intrinsically arrogant process of inculcating students with patterns of reasoning adopted by the instructor, herself, and becomes seen by all as a progressively personal voyage into unique semantic spaces, independent of those occupied by the authority.

c) Conceiving of open-ended, gradeless assessment tools that would integrate well with the structure of the instructional method per se and form a closed loop that undergirds the learning process instead of diluting it.

\section{Conclusion}

Metalogic and improvisatory, open-ended curricula have not been the standard accompaniments of education. Traditionally and colloquially, based on the author's experience, they have been considered as either insufficiently effective in promoting better learning to justify their inclusion to instructional methodologies or as causes of confusion that directly obstruct the learning process. Consequently, metacognitive skills are rarely fostered in higher, let alone primary education. Shaky metacognitive grounds whose volatile semantics eludes iterative representations appear to be structurally at odds with the aspiration of mainstream instructors to maintain, first and foremost, orderliness and predictable flow in the class, which minimizes the invocation of these grounds. Since metacognitive insights pertaining to the learned subject and the learning process are conditioned by abstract reflections (Tanner, 2012), which feed on unstructured, free flights of imagination, their inclusion to the coursework has been seen as a hindrance to a streamlined instruction and explains their sporadic fosterage in higher education settings. Openended curricula require similar persistency of instructors in finding innovative ways to guide the class, which is challenging to those who prefer delivering the content from one generation to another as if on a conveyer belt. Therefore, both of these central aspects of the instructional method elaborated here clash with the inclination to robotize education by bringing about an element of humanness to it, extremely important in the context of teaching natural science in today's academia where the ideals of STEM and its likes increasingly linearize and narrow the instructional content and style (Uskoković, 2017). All this is to say that instructional methods based on the two aforementioned principles - metacognition and open-endedness - must continue to evolve and be relentlessly experimented with. One such experimental 
method of instruction, open-ended and metacognitive, rooted in the freedom to improvise and never follow the same path twice, was elaborated on these pages.

At the very end of this journey, after this experimental model of instruction has been proposed, Cioran's thought that opened this discourse could be revisited in a new light. It highlights the importance of collective uncertainties as great communal connecters as well as of the incessant need for both the instructors and the students to be surprised by constant quests for novel directions to head to and novel ideas to dig if a sense of intellectual satisfaction is to dawn on the classroom as a whole, be it the conventional, indoor one or the livelier and imaginary, outdoor, open-sky one. After all, impression and expression are as naturally tied to each other as breathing in and out are and lest a teacher transform into an epitome of the leader who listens not and who is thus bound to become surrounded by those who have nothing to say (Stanley, 2006), she should learn to listen and receive in synchrony with sending out informative ideas, remembering along the way the story of Momo and her ability to help people find solutions to their problems by simply listening (Ende, 1974) - really listening, deeply and darkly. Indeed, experienced teachers all the world over confirm that the most productive teaching moments are regularly followed or preceded by illuminative insights arrived at by the teacher herself. Closing the gates for the inflow of these surprising realizations to the space of one's mind and resisting the change of one's deepest convictions and modes of being in communication with another would imply essentially futile words and expressions to come out of one's mouth.

Therefore, a sense of purposelessness levitates above the idea of presenting any preconceived ideas or principles to students in the classroom adopting this model, installing a process of co-discovery through the interbreeding of perspectives that are unique to each class in its place. In the same spirit, a spoken word poet, standing on the stage and delivering waves of heartwarming poetry, says this: "There are plenty of things I have trouble understanding. So I write poems to figure things out. Sometimes the only way I know how to work through something is by writing a poem. And sometimes I get to the end of the poem and look back and go, 'Oh, that's what this is all about', and sometimes I get to the end of the poem and haven't solved anything, but at least I have a new poem out of it... And I wondered whether I'd get to the end of this talk and finally have figured it all out, or not” (Kay \& Janowitz, 2011). Falling apart into metacognitive waters of incoherency, where all Alphavillian machines cease to work and begin to rust and where we come to remember that we are humans, an insight whence the dozy creative forces in us may begin to awake, is inevitable every now and then in the creative chaos of the classroom envisaged here and must happen at least once in any veritable portrayal of it, which is why this sentence will suddenly break, start to whirl and silhouette in place, drifting like a revenant sailboat into the night. For, without the immanence of occasional descents into epistemic disarrays, no penultimate message of education can be gotten across, which is to enliven the spirits, to resist the deadness of a robotized intellect and promote life in all its erraticism, waywardness and freeness of an infant at play. And there, Nietzsche says, in the chaos of a myriad of mental spheres spinning wildly around, within and atop one another is where the most creative ideas, stars as it were, are being born.

Availability of data and material: Data for this study are available upon request.

Competing interests: There are no conflicts of interest to declare.

Funding: No funding was received for this study.

Authors' contributions: The author conceived, implemented, interpreted and wrote this study.

Acknowledgments: The author thanks Daniela ValdezJasso from University of Illinois in Chicago (UIC) and University of California in San Diego (UCSD) for assistance with the student participation and survey distribution. The author also thanks the students from the Spring 2016 BIOE415 class at UIC and former colleagues at Chapman University for their attending the lectures and participating in the surveys. The study makes reference to research supported by the NIH R00-DE021416.

\section{References}

Anderson, L.W., Krathwohl, D.R. (2001). A taxonomy for learning, teaching, and assessing: A revision of Bloom's taxonomy of educational objectives. New York: Longman.

Ashby, R. (1952). Design for a brain. London: Chapman \& Hall.

Ashby, R. (1956). An introduction to cybernetics. London: Chapman \& Hall.

Baird, J. R. (1986). Improving learning through enhanced metacognition - a classroom study. European Journal of Science Education 8, 263-282.

Bateson, G. (1979). Mind and Nature: A necessary unity (pp. 199). Cresskill, NJ: Hampton Press. 
Biggs, J. (1988). The role of metacognition in enhancing learning. Australian Journal of Education 32, 127-138.

Bjork, R. A. (1999). Assessing our own competence: Heuristics and illusions. In D. Gopher \& A. Koriat (Eds.), Cognitive regulation of performance: Interaction of theory and application ( $\mathrm{pp.}$.435459). Cambridge, MA: MIT Press.

Bloom, B. (1956). Taxonomy of educational objectives: The classification of educational goals. New York: McKay.

Cioran, E. M. (1973). The trouble with being born (pp. 12). New York: Arcade.

Chesterton, G. K. (1925). The everlasting man. In: The collected works of G. K. Chesterton, Volume 2 (pp. 388). San Francisco, CA: Ignatius Press.

Ende, M. (1974). Momo. London: Puffin Books.

Ernest, J. B., Reinholz, D. L. (2018). Off topic but on point: student talk in an undergraduate geometry classroom. Journal for STEM Education Research 1, 103-118 (2018).

Erwin, R. W. (1985). Research currents for developmental reading educators: Metacognition. Research \& Teaching in Developmental Education 2, 19-23.

Feynman, R. P. (1998). The meaning of it all: Thoughts of a citizen scientist (pp. 47). Reading, MA: Helix Books.

Flavell, J. H. (1976). Metacognitive aspects of problem solving. In: L. B. Resnick (Ed.), The nature of intelligence (pp. 231-235). Hillsdale, NJ: Lawrence Erlbaum.

Fletcher, A. (2001). The art of looking sideways. London: Phaidon.

Ford, J. K., Weissbein, D. A., Smith, E. M., Gully, S. M., Salas, E. (1998). Relationships of goal orientation, metacognitive activity, and practice strategies with learning outcomes and transfer. Journal of Applied Psychology 83, 218-233.

Fox, E., Riconscente, M. (2008). Metacognition and self-regulation in James, Piaget, and Vygotsky. Educational Psychology Review 20, 373-389.

Friere, P. (1993). Pedagogy of the oppressed. New York: Continuum Books.

Georghiades, P. (2004). Making pupils' conceptions of electricity more durable by means of situated metacognition. International Journal of Science Education 26, 85-99.

Glanville, R. (2003). Machines of wonder and elephants that float through air. Cybernetics \& Human Knowing 10, 91-105.

Godard, J.-L. (1965). Alphaville. Paris: Athos.

Godard, J.-L. (1998). Histoire(s) du cinema: The signs among us. Neuilly-sur-Seine: Gaumont.

Gorgen, R., Huemer, S., Schulte-Korne, G., Moll K. (2020). Evaluation of a digital game-based reading training for German children with reading disorder. Computers \& Education 150, 103834.

Heer, R. (2012). A model of learning objectives-based on a taxonomy for learning, teaching, and assessing: A revision of Bloom's taxonomy of educational objectives. Ames, IA: Center for Excellence in Learning and Teaching, lowa State University.

Hooks, B. (1994). Teaching to transgress: Education as the practice of freedom. New York: Routledge.

Hubbard, K. E., Brown, R., Deans, S., Garcia, M. P., Pruna, M.-G., Mason, M. J. (2017). Undergraduate students as co-producers in the creation of first-year practical class resources. Higher Education Pedagogies 2, 58-78.

Karpicke, J. D., Butler, A. C., Roediger III, H. L. (2009). Metacognitive strategies in student learning: Do students practise retrieval when they study on their own?, Memory 17, 471-479.
Kay, S., Janowitz, S. (2011). B: 'If I Should Have a Daughter...'. New York: Hachette Books.

Nietzsche, F. (1891). Thus Spake Zarathustra (pp. 6). Mineola, NY: Dover.

Liuta, A. V., Perig, A. V., Afanasieva, M. A., Skyrtach, V. M. (2019). Didactic games as student-friendly tools for learning hydraulics in a technical university's undergraduate curriculum. Industry and Higher Education 33, 198-213.

Maturana, H., Verden-Zöller, G. (2008). The origin of humanness in the biology of love. Charlottesville, VA: Imprint Academic.

McCulloch, W. (1965). Embodiments of mind. Cambridge, MA: MIT Press.

Moshman, D. (1990). The Development of metalogical understanding. In: W. F. Overton \& L. Erlbaum (Eds.), Reasoning, necessity, and logic: Development perspectives (pp. 205-225). Hillsdale, NJ: Lawrence Erlbaum.

Moshman, D. (2003). Intellectual freedom. Liberal Education 89, 30-37.

Nakagawa, M., Yamanaka, S. (2010). Reprogramming of somatic cells to pluripotency. Advances in Experimental Medicine and Biology_695, 215-224.

Perlis, A. J. (1982). Epigrams in programming. SIGPLAN Notices 17, 9.

Perry, J., Lundie, D., Golder, G. (2018). Metacognition in schools: what does the literature suggest about the effectiveness of teaching metacognition in schools? Educational Review 71, 483-500.

Pintrich, P. R. (2002). The role of metacognitive knowledge in learning, teaching, and assessing. Theory into Practice 41, 219-225.

Pokay, P., Blumenfeld, P. C. (1990). Predicting achievement early and late in the semester: The role of motivation and use of learning strategies. Journal of Educational Psychology 82, 41-50.

Prensky, M. (2001). Digital natives, digital immigrants part 1. On the Horizon 9, 1-6.

Rothko, M. (1934). Sketchbook. In: M. Lopez-Remiro (Ed.), Writings on Arts: Mark Rothko (pp. 14). New Haven, CT: Yale University Press.

Roud, R. (1968). Introduction. In: J. Narboni \& T. Milne (Eds.), Godard on Godard (pp. 8). New York: Da Capo Press.

Santamaria, C., Tse, P. P., Moreno-Rios, S., Garcia-Madruga, J. A. (2013). Deductive reasoning and metalogical knowledge in preadolescence: A mental model appraisal. Journal of Cognitive Psychology 25, 192-200.

Simmons, T. L. (2002). Climbing Parnassus: A new apologia for Greek and Latin (pp. 2). Wilmington, DE: ISI Books.

Smith, L. (1996). Conclusion: Piaget's epistemology: Psychological and educational assessment. In: L. Smith (Ed.), Critical Readings on Piaget (pp. 478-521). London: Routledge.

Tanner, K. D. (2012). Promoting student metacognition. CBE - Life Sciences Education 11, 113-120.

Stanley, A. (2006). Next Generation Leader (pp. 111). Colorado Springs, CO: Multmonah.

Thoreau, H. D. (1854) Walden (pp. 130). Huntington, VW: Empire Books.

Uskoković, V. (2009). On the light doves and learning on mistakes. Axiomathes: An International Journal in Ontology and Cognitive Systems 19, 17-50. 
Uskoković, V. (2017). Rethinking active learning as the paradigm of our times: Towards poetization of education in the age of STEM. Journal of Materials Education 39, 241-258.

Uskoković, V. (2018a). Flipping the flipped: The co-creational classroom. Research and Practice in Technology Enhanced Learning 13, 11.

Uskoković, V. (2018b). Revisiting the relevance of conceptualism of Godard's film. Journal for Religion, Film and Media 4, 83-113.

Uskoković, V., Lee, K., Lee, P. P., Fischer, K. E., Desai, T. A. (2012a). Shape effect in the design of nanowire-coated microparticles as epithelial drug delivery devices. ACS Nano 6, 7832-7841.

Uskoković, V., Lee, P. P., Walsh, L., Fischer, K. E., Desai, T. A.

(2012b). Silicon nanowire coated microparticles as epithelial drug delivery devices. The effect of PEGylation on particleepithelium interactions. Biomaterials 33, 1663-1672.

Veldkamp, A., Daemen, J., Teekens, S., Koelewijn, S., Knippels, M. C. P. J., van Joolingen, W. R. (2020). Escape boxes: Bringing escape room experience into the classroom. British Journal of Educational Technology. DOI: 10.1111/bjet.12935.

von Foerster, H., Poerksen, B. (2002). The metaphysics of ethics: A conversation. Cybernetics \& Human Knowing 9, 149-157.

Winograd, T., Flores, F. (1987). Understanding computers and cognition: A new foundations for design. Norwood, N): Ablex.

Wittgenstein, L. (1918). Tractatus logico-philosophicus. London: Routledge.

Worley, P. (2018). Plato, metacognition and philosophy in schools. Journal of Philosophy in Schools 5, 1.

Wu, V. M., Tang, S., Uskoković, V. (2018). Calcium phosphate nanoparticles as intrinsic inorganic antimicrobials: The antibacterial effect. ACS Applied Materials and Interfaces 10, 34013-34028.

Yen, M. H., Wang, C. Y., Chang, W. H., Chen, S. F., Hsu, Y. S., Liu, T. C. (2018). Assessing metacognitive components in self-regulated reading of science texts in e-based environments. International Journal of Science and Mathematics Education 16, 797-816.

Zawadzka, K., Simkiss, N., Hanczakowski, M. (2018). Remind me of the context: Memory and metacognition at restudy. Journal of Memory and Language 101, 1-17.

Zimmerman, B. J. (1995). Self-regulation involves more than metacognition: A social cognitive perspective. Educational Psychologist 30, 217-221. 